\title{
Assessment of changes in soil properties, nutrient availability and yield of paddy as influenced by cultivation of green manuring crop
}

\section{DIPANKAR DEY AND DIPAK NATH}

Received : 21.02.2015; Accepted : 28.05.2015

\author{
MEMBERS OF RESEARCH FORUM: \\ Corresponding author : \\ DIPANKAR DEY, Krishi Vigyan \\ Kendra, Divyodaya, West Tripura, \\ Chebri, KHOWAI (TRIPURA) INDIA \\ Email: spd020@yahoo.co.in
}

\section{Co-authors :}

DIPAK NATH, Krishi Vigyan Kendra, Divyodaya, West Tripura, Chebri, KHOWAI (TRIPURA) INDIA

\section{Summary}

An experiment was conducted at West Tripura district to evaluate the soil properties and nutrient availability as influenced by cultivation of green manuring crop in acidic soil condition of West Tripura district. Soil samples were collected randomly in the fields for analysis of nutrients and organic carbon and other physical properties. The study revealed that the change in soil physical properties and nutrient availability was significantly increased under the green manuring practice. The green manuring crop dhaincha and mung bean was grown on the plots and it was incorporated into the soil by ploughing before attaining the flowering stage. Further the land was left for 24 days for decomposition of green manure. Highest grain yield of paddy (5.5 $\mathrm{t} / \mathrm{ha}$ ) was observed in dhaincha- aman paddy- potato cropping system whereas the lowest grain yield of paddy ( $3.5 \mathrm{t} / \mathrm{ha}$ ) was obtained in fallow- aman paddy- potato cropping system. The grain yield obtained from mung bean- aman paddy- potato cropping system was $4.8 \mathrm{t} / \mathrm{ha}$.

Key words : Green mauring crop, Paddy, Cropping system

How to cite this article : Dey, Dipankar and Nath, Dipak (2015). Assessment of changes in soil properties, nutrient availability and yield of paddy as influenced by cultivation of green manuring crop. Asian J. Soil Sci., 10(1) : 158-161. 